\title{
Effects of Engine Cooling Water Temperature on Performance and Emission Characteristics of a Compression Ignition Engine Operated with Biofuel Blend
}

\author{
Abul K. Hossain ${ }^{* 1}$, David I. Smith ${ }^{2}$, Philip A. Davies ${ }^{3}$ \\ ${ }^{1}$ Sustainable Environment Research Group (SERG), School of Engineering and Applied Science, \\ Aston University, Birmingham B4 7ET, United Kingdom \\ e-mail: a.k.hossain@ aston.ac.uk \\ ${ }^{2}$ Sustainable Environment Research Group (SERG), School of Engineering and Applied Science, \\ Aston University, Birmingham B4 7ET, United Kingdom \\ e-mail: d.i.smith@aston.ac.uk \\ ${ }^{3}$ Sustainable Environment Research Group (SERG), School of Engineering and Applied Science, \\ Aston University, Birmingham B4 7ET, United Kingdom \\ e-mail: p.a.davies@aston.ac.uk
}

\begin{abstract}
Cite as: Hossain, A. K., Smith, D. I., Davies, P. A., Effects of Engine Cooling Water Temperature on Performance and Emission Characteristics of a Compression Ignition Engine Operated with Biofuel Blend, J. sustain. dev. energy water environ. syst., 5(1), pp 46-57, 2017, DOI: http://dx.doi.org/10.13044/j.sdewes.d5.0132
\end{abstract}

\begin{abstract}
The temperature of the coolant is known to have significant influence on engine performance and emissions. Whereas existing literature describes the effects of coolant temperature in engines using fossil derived fuels, very few studies have investigated these effects when biofuel is used. In this study, Jatropha oil was blended separately with ethanol and butanol. It was found that the $80 \%$ jatropha oil $+20 \%$ butanol blend was the most suitable alternative, as its properties were closest to that of fossil diesel. The coolant temperature was varied between $50{ }^{\circ} \mathrm{C}$ and $95{ }^{\circ} \mathrm{C}$. The combustion process enhanced for both diesel and biofuel blend, when the coolant temperature was increased. The carbon dioxide emissions for both diesel and biofuel blend were observed to increase with temperature. The carbon monoxide, oxygen and lambda values were observed to decrease with temperature. When the engine was operated using diesel, nitrogen oxides emissions correlated in an opposite manner to smoke opacity; however, nitrogen oxides emissions and smoke opacity correlated in an identical manner for biofuel blend. Brake specific fuel consumption was observed to decrease as the temperature was increased and was higher on average when the biofuel was used. The study concludes that both biofuel blend and fossil diesel produced identical correlations between coolant temperature and engine performance. The trends of nitrogen oxides and smoke emissions with cooling temperatures were not identical to fossil diesel when biofuel blend was used in the engine.
\end{abstract}

\section{KEYWORDS}

Biofuel, Compression ignition engine, Coolant temperature, Emission, Performance.

\section{INTRODUCTION}

Fossil diesel is widely used in a variety of applications, including transportation, combined heat and power generation, industry and irrigation. Hence, it is a large

\footnotetext{
* Corresponding author
} 
contributor to global greenhouse gas emissions and therefore the need to find a renewable alternative fuel is paramount. Use of biofuels as an alternative fuel have been around since before the 1850's, and early cars such as the 'Ford Model T' was originally designed to run on ethanol. However, investments in the biofuels industry began to rise after two world wars and the oil crisis during the late 1900's [1]. The use of first generation biofuels has been debated, as there would be increased prices in the food industry, especially in developing countries [2]. Sustainable $2^{\text {nd }}$ generation biofuels produced from non-food materials can be used as an alternatives to diesel in the Compression Ignition (CI) engines; engine performance and exhaust emission results varied depending on the type of biofuels and engines used. Biofuels could offset about $80 \%$ of the life cycle greenhouse gas emissions by replacing fossil diesel use in the internal combustion engines [3]. Engine modifications such as optimisation of compression ratio, injector geometry, cylinder and piston materials, and dual fuelling techniques are recommended for adapting waste derived pyrolysis oils use in the engines [4]. Bergthorson et al. [5] reported that oxygenated biofuels produced lower soot emissions than fossil based hydrocarbon fuels. Biodiesel produced less Carbon dioxide $\left(\mathrm{CO}_{2}\right)$ and unburnt Hydrocarbon (HC) emissions when compared with fossil diesel [6]. On the other hand, biodiesel emits high Nitrogen oxides $\left(\mathrm{NO}_{\mathrm{x}}\right)$ and Particulate emissions (PM), which can be reduced by emulsification techniques [7]. Rakopoulos et al. [8] reported that the ignition delay did not change but the maximum in-cylinder pressure was decreased when biofuels were used instead of fossil diesel. Alcohols are being used as a blend component with biofuels and/or diesel to improve the combustion characteristics and to reduce pollution. Compared to pure diesel operation, low $\mathrm{NO}_{\mathrm{x}}$ and $\mathrm{CO}_{2}$ emissions have been observed with ethanol-diesel fuel blends [9, 10]. Lujaji et al. [11] reported that biofuel blend containing cotton oil, butanol and diesel gave lower thermal efficiency than pure diesel. Smoke and $\mathrm{NO}_{\mathrm{x}}$ emissions were found to decrease by a small amount when the butanol blends were used. On the other hand, $\mathrm{CO}_{2}$ and $\mathrm{HC}$ emissions were observed to increase when butanol-diesel blends are used [12]. Jatropha Oil (JO) is non-edible plant oil with the potential to be utilised as a diesel substitute in CI engines [13]. Kumar et al. [14] reported that Jatropha-butanol blends gave higher thermal efficiency and lower brake specific fuel consumption than diesel. Similar results were reported when Jatropha biodiesel-butanol blends were used instead of neat Jatropha biodiesel [15]. In this study, jatropha-alcohol blends will be tested in the CI engine to investigate the effect of cooling water temperature on engine performance and exhaust emission.

$\mathrm{CI}$ engines are regarded as the most efficient type of internal combustion engines as they offer good fuel economy and low $\mathrm{CO}_{2}$ emissions. However, at higher loads, considerable amount of particulate matter and nitrogen oxide $\mathrm{NO}_{\mathrm{x}}$ are produced from $\mathrm{CI}$ engines $[16,17]$. The cooling system in CI engines maintain the thermal integrity of the engine structure, as the coolant passes through the case (jacket) surrounding the engine. Therefore, the temperature of combustion within the engine is directly affected by the cooling system. In addition, the cooling system also has an influence on the lubricating oil temperature and the exhaust recirculation gas temperature [18]. Effects on engine performance due to the changes in the temperature of the engine coolant and intake air have been previously investigated, when operated with fossil diesel [19-25]. It was reported that the $\mathrm{HC}$ emissions were $25 \%$ lower and $\mathrm{NO}_{\mathrm{x}}$ emissions were $7 \%$ higher when the coolant temperature was increased [20]. $\mathrm{NO}_{\mathrm{x}}$ and soot emissions increased as the air intake temperature was increased [21, 22]. Torregrosa et al. [23] reported that the ignition delay decreases as the coolant temperature increases. They also reported that increased air temperature influenced $\mathrm{NO}_{\mathrm{x}}$ and $\mathrm{HC}$ emissions $-\mathrm{NO}_{\mathrm{x}}$ gas emission increased at high temperatures for all loads and $\mathrm{HC}$ emissions decreased at high temperatures [23]. It was reported that lower coolant temperature may reduce $\mathrm{NO}_{\mathrm{x}}$ emissions by up to $30 \%$; with minor improvements to specific fuel consumption, Carbon 
monoxide (CO) and HC emissions [24]. The chemical composition and physicochemical properties of the biofuels are different than fossil diesel (and gasoline). Hence, it is expected that the effects of coolant temperature on biofuels combustion and exhaust emissions would not be similar to that of standard fossil diesel/gasoline operation. Although researchers investigated the effects of coolant temperature on engine performance and emissions fuelled with fossil diesel; rarely any literature exists investigating the same when biofuel is used in the engine.

The aim of this study is to investigate the effects of cooling water temperature on the performance and exhaust emission characteristics of a CI engine operated with biofuel blend. Jatropha-alcohol blends will be created and physical and chemical properties of these blends will be measured. The properties of the fuels will be analysed and compared against each other, with diesel as the benchmark. A 2-cylinder CI engine will be tested using diesel and a chosen biofuel blend. The temperature of the cooling water will be varied. Engine performance and emission results will then be analysed and discussed to see how the engine performance and emissions vary with the coolant temperature.

\section{MATERIALS AND METHODS}

The materials and methods used in this study were:

- Sourcing biofuel and preparation of the biofuel blends;

- Measurement of the properties of the fuels (including equipment used, standards and accuracy);

- Preparation of the engine test rigs (including instrumentations) and associated measurements. They are explained below in two categories.

\section{Biofuels and properties}

Standard diesel was sourced from a local service station. Fisher Scientific brand ethanol and butanol were used to prepare biofuel blends. JO is a renewable biofuel, oil was obtained through a supplier, and was manually filtered using a 1 micron sock filter to remove dissolved solids. Fuel properties of JO, diesel, Ethanol (ET), Butanol (BL) and blends $(80 \% \mathrm{JO}+20 \% \mathrm{BL}, 70 \% \mathrm{JO}+30 \% \mathrm{BL}, 80 \% \mathrm{JO}+20 \% \mathrm{ET}$, and $70 \% \mathrm{JO}+$ $30 \%$ ET) were measured internally using various analytical equipment (Parr Bomb Calorimeter, SETA Flash Point Tester, Hydrometer, Canon Fenski U-tube Viscosity Meter). Viscosities of fuels were measured at various temperatures using a constant temperature bath. All measurements were repeated three times, and an average value was calculated and used in the analysis. Cetane Numbers $(\mathrm{CN})$ of pure JO, BL and fossil diesel were collected from literature [26-28]; however, $\mathrm{CN}$ of the JO blends were not measured in this study.

\section{Engine testing and measurements}

A 2-cylinder Yanmar 2TNV70 engine was used in this experiment - specification of the engine is shown in Table 1. The engine was connected to a GUNT CT-300 test stand (Figure 1). The engine was tested at constant speed of 2,500 rpm and at various load settings $(60 \%, 80 \%$ and $100 \%$ load). The engine loads were set in Newton-meter $(\mathrm{Nm})$ as percentage torques of the rated power output, e.g. $100 \%$ load means the torque required for rated power output at 2,500 rpm.

The performance parameters were recorded from the control panel of the test rig are: speed $(\mathrm{rpm})$, torque $(\mathrm{Nm})$, air intake (litres/min), air temperature $\left({ }^{\circ} \mathrm{C}\right)$, fuel inlet temperature $\left({ }^{\circ} \mathrm{C}\right)$, exhaust gas temperature $\left({ }^{\circ} \mathrm{C}\right)$, coolant water inlet and outlet temperatures $\left({ }^{\circ} \mathrm{C}\right)$, oil temperature $\left({ }^{\circ} \mathrm{C}\right)$, oil pressure (bar) and the time taken to consume a set volume of fuel. The emissions of $\mathrm{CO}, \mathrm{CO}_{2}, \mathrm{HC}, \mathrm{NO}_{\mathrm{x}}$, and $\mathrm{O}_{2}$ gases in the exhaust were measured using a Bosch BEA 850 analyser. Smoke opacity values were measured 
using a BOSCH Smoke meter. An asynchronous motor was used to apply load on the engine.

Table 1. Specification of the CI engine used in the experiment

\begin{tabular}{c|c}
\hline Manufacturer & Yanmar \\
Model & $2 \mathrm{TNV} 70$ \\
No. of cylinders & 2 \\
Type of injection & Indirect \\
Cooling system & Liquid cooled \\
Bore $\times$ Stroke $[\mathrm{mm}]$ & $70 \times 74$ \\
Displacement $[\mathrm{L}]$ & 0.570 \\
Rated output & $7.5 \mathrm{~kW}$ at $2,500 \mathrm{rpm}$ \\
\hline
\end{tabular}

The engine has an unconventional liquid cooling system, which uses water supplied directly from the mains (Figure 1). There is no radiator within this set-up, and the outlet water, from the engine jacket, is sent to an external reservoir. This allows greater control of the cooling water flow rate. The outlet cooling water temperature was varied by using the flow rate control valve. As the flow rate is increased, the outlet water temperature decreases. Engine performance and emission parameters were recorded for each load settings.

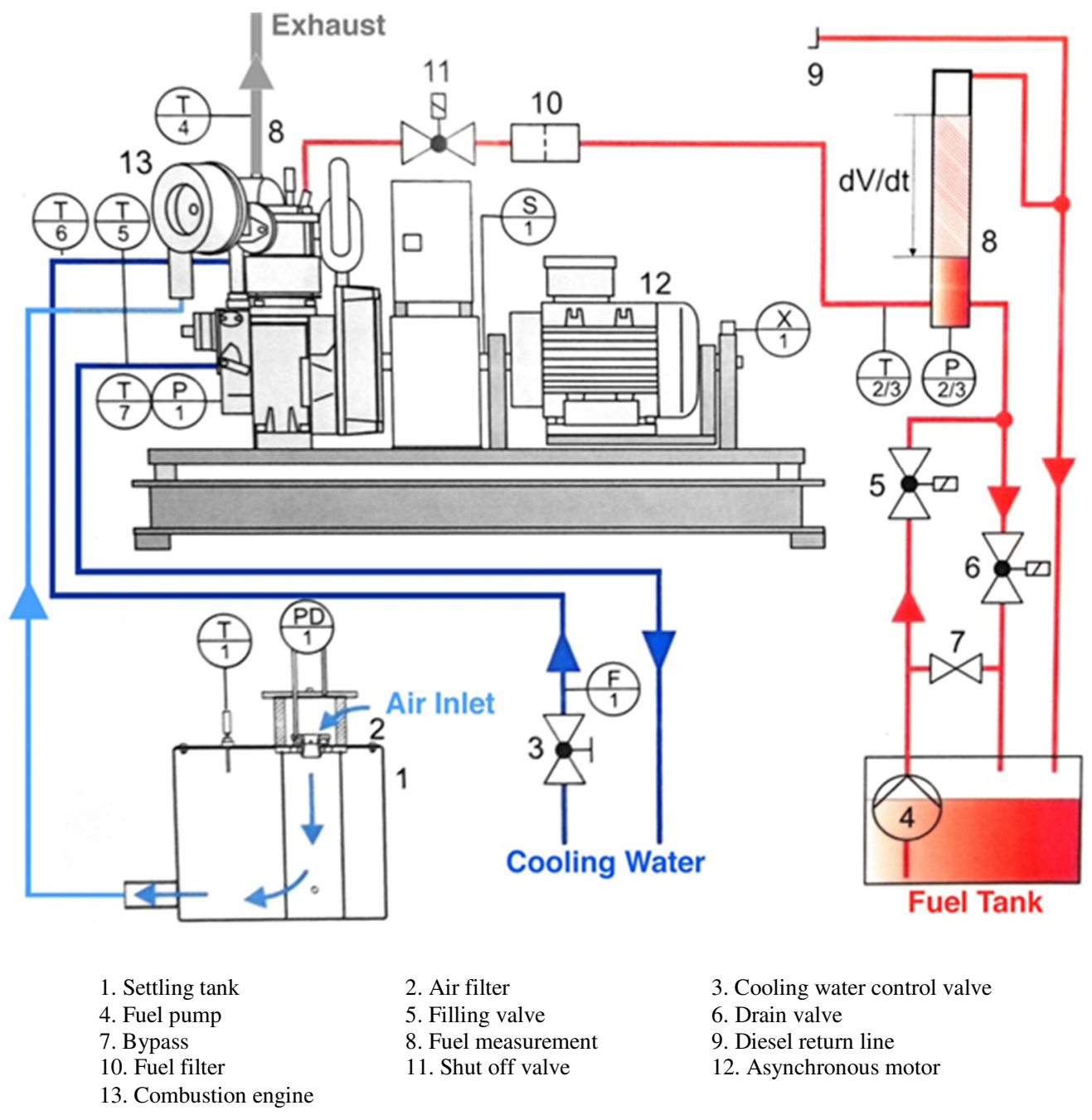

Figure 1. GUNT CT-300 experimental test rig 


\section{RESULTS AND DISCUSSION}

The properties of the fuel blends and engine test results are discussed separately in the following sub-sections. The blend results were compared with the corresponding fossil diesel results.

\section{Fuel properties}

Fuel properties of pure diesel, jatropha, ET, BL and JO blends are shown in Table 2. The density of JO is considerably higher than the density of diesel and both of the alcohols. The ignition delay could be longer for fuels with high density. When JO is blended with the alcohols, the density of the blend decreases as the proportion of alcohol is increased. The JO blends containing ET are less dense when compared to the fuel blends containing BL, due to the density of pure ET being lower than pure BL. The viscosity of the fuel is important, higher the viscosity larger will be the fuel droplets sizes and hence poorer combustion inside the engine cylinder. It was found that the JO-alcohol based fuel blends have a lower viscosity than $100 \%$ pure JO at room temperature, due to the low viscosities of ET and BL. However, the kinematic viscosities of all the blends are still considerably higher than the viscosity of $100 \%$ pure diesel. The $70 \% \mathrm{JO}+30 \% \mathrm{ET}$ blend has the lowest measured viscosity out of all four blends. Figure 2 shows how the kinematic viscosity of the fuels varied as the temperature was increased. At $80{ }^{\circ} \mathrm{C}$, the kinematic viscosities of all fuel blends are comparable to the viscosity of fossil diesel. The flash point temperature for $100 \%$ pure $\mathrm{JO}$ is much higher than that of diesel (Table 2). The $80 \% \mathrm{JO}+20 \% \mathrm{BL}$ blend has reasonable flash point temperature.

Table 2. Fuel properties of jatropha, diesel and blends

\begin{tabular}{cccccc}
\hline Fuel sample & $\begin{array}{c}\text { Viscosity at } \\
\text { room temp. } \\
\left(22.8^{\circ} \mathrm{C}\right)[\mathrm{cSt}]\end{array}$ & $\begin{array}{c}\mathrm{HHV} \\
{[\mathrm{MJ} / \mathrm{kg}]}\end{array}$ & $\begin{array}{c}\text { Density } \\
{\left[\mathrm{kg} / \mathrm{m}^{3}\right]}\end{array}$ & $\begin{array}{c}\text { Flash point } \\
{\left[{ }^{\circ} \mathrm{C}\right]}\end{array}$ & $\mathrm{CN}$ \\
\hline 100\% Diesel & 3.28 & 44.95 & 835.00 & 62.50 & 50.20 \\
$100 \% \mathrm{JO}$ & 57.07 & 39.45 & 914.33 & 206.00 & 44.60 \\
$100 \% \mathrm{BL}$ & 35.69 & 35.69 & 810.00 & 34.33 & 17.00 \\
$100 \% \mathrm{ET}$ & 28.11 & 28.11 & 790.00 & 17.00 & 8.00 \\
$80 \% \mathrm{JO}+20 \% \mathrm{BL}$ & 24.16 & 38.50 & 894.00 & 38.67 & - \\
$70 \% \mathrm{JO}+30 \% \mathrm{BL}$ & 18.08 & 37.14 & 883.33 & 36.33 & - \\
$80 \% \mathrm{JO}+20 \% \mathrm{ET}$ & 19.70 & 36.61 & 890.67 & 17.00 & - \\
$70 \% \mathrm{JO}+30 \% \mathrm{ET}$ & 13.65 & 35.94 & 878.00 & 17.00 & - \\
\hline
\end{tabular}

Heating value of the fuel is another important parameter, higher heating value will produce higher power output i.e., for the same engine load less fuel is required for fuel with higher calorific value. Diesel has the highest heating value, whilst ET has the lowest. It was observed that as the proportion of alcohol was increased in the blends, the Higher Heating Value (HHV) decreased. Blends containing ET have a lower HHV, on average, when compared to blends containing BL. The $80 \% \mathrm{JO}+20 \% \mathrm{BL}$ blend has the highest $\mathrm{HHV}$ and is close to the value of $100 \%$ pure $\mathrm{JO}$, making it the most desirable blend to use in the engine. $\mathrm{CN}$ for diesel is the highest and lowest for ET. CN of JO-alcohol blends were not measured. BL has a higher $\mathrm{CN}$ than ET, it can be assumed that the fuel blends made of BL have a higher $\mathrm{CN}$, on average, when compared to the ET based blends.

By comparing the properties of $\mathrm{JO}$ and $\mathrm{JO}$-alcohol blends with the corresponding properties of the standard fossil diesel, JO-BL blends were found to be feasible fuel for the diesel engine. Furthermore, among the JO-BL blends, it was determined that $80 \%$ JO 
$+20 \%$ BL was the most suitable biofuel blend to use in the engine, as its measured properties were closest to that of pure diesel.

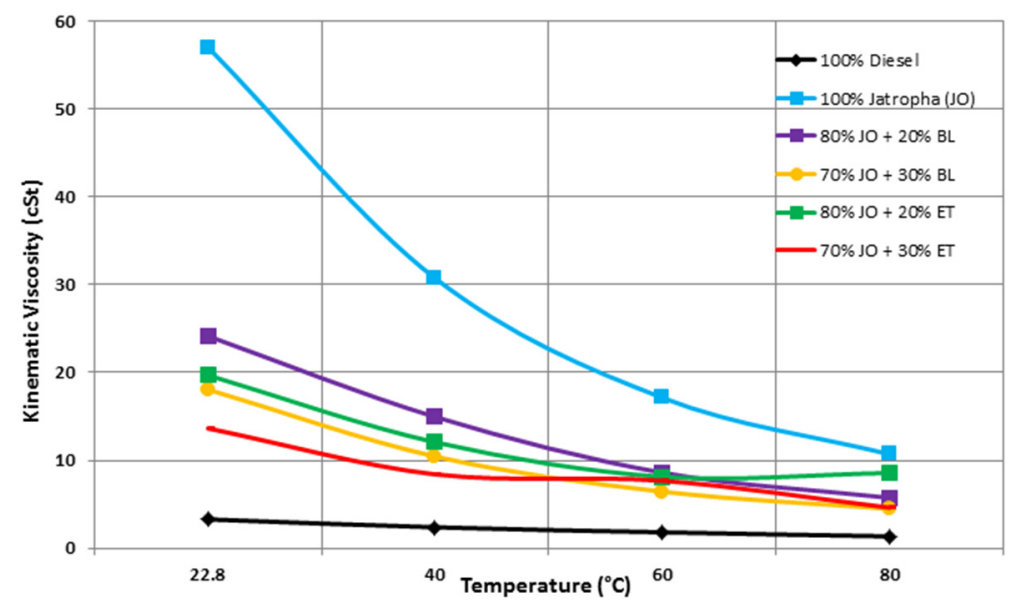

Figure 2. Viscosity results at various temperatures

\section{Engine test results}

The $80 \% \mathrm{JO}+20 \% \mathrm{BL}$ biofuel blend was used in the engine at various loads and coolant temperature. The performance and emission results were compared with pure diesel operation (Figures 3-5). At full load (100\% load), the high content of BL in the blend caused a high concentration of butanol vapour in the combustion chamber which caused minor engine knocking, and hence $100 \%$ biofuel results are not shown in the figures. It was observed that for both biofuel and diesel, as the cooling water temperature was increased, there was an increase in the $\mathrm{CO}_{2}$ emissions, for all loads (Figure 3a). The increase in $\mathrm{CO}_{2}$ emissions caused due to better burning of the fuel in the combustion chamber. $\mathrm{CO}_{2}$ emissions trends were identical for both fuels; however, at low load, the $\mathrm{CO}_{2}$ emissions were slightly higher in the case of JO-BL blend (Figure 3a). It was seen that at $80 \%$ load, diesel $\mathrm{CO}$ emissions didn't change much with the increase in combustion temperature; whereas biofuel $\mathrm{CO}$ emissions decreased by about $31 \%$ when the temperature was increased from 60 to $90{ }^{\circ} \mathrm{C}$. This can be explained as, at high combustion temperature, combustion of biofuels improved due to the higher oxygen content in the biofuel blend. As a result of improved combustion, biofuel $\mathrm{CO}$ emissions decreased. However, at partial load, trend of biofuel $\mathrm{CO}$ emissions with the water temperature was different, $\mathrm{CO}$ emissions were minimum at about $80^{\circ} \mathrm{C}$ (Figure $3 \mathrm{~b}$ ). The reason for this could be that the change in the $\mathrm{CO}$ emissions were very low compared to the measurement accuracy of the instrument used in this study. In addition, it was observed that, in general, biofuel $\mathrm{CO}$ emissions were higher than diesel. Compared to fossil diesel operation, higher amount of biofuel blend was combusted in order to produce the same power output. Hence, it was believed that, for the same engine load, higher amount of biofuel burning caused higher $\mathrm{CO}$ emissions than that of fossil diesel. Figure $3 \mathrm{c}$ shows that the $\mathrm{O}_{2}$ emissions decreased by a small amount with the increase in cooling temperatures for both biofuel and diesel fuels. As the quality of combustion increases at higher temperatures, more oxygen is used within this process; therefore $\mathrm{O}_{2}$ emissions are expected to decrease. However, for all loads, JO-BL blend emitted lower $\mathrm{O}_{2}$ gases than diesel (Figure 3c), most of the oxygen present in the biofuel was converted to either $\mathrm{CO}$ or $\mathrm{CO}_{2}$ gases (Figure $3 \mathrm{a}$ and $3 \mathrm{~b}$ ).

In the case of JO-BL blend operation and at $60 \%$ load, it was observed that the $\mathrm{NO}_{\mathrm{x}}$ emissions decreased as the cooling water temperature was increased. However after reaching a minimum value, the $\mathrm{NO}_{\mathrm{x}}$ emissions began to increase (Figure 4a). On the 
other hand, at $80 \%$ load, the opposite was observed; the $\mathrm{NO}_{\mathrm{x}}$ emissions increased with cooling water temperature until reaching a maximum value; then $\mathrm{NO}_{\mathrm{x}}$ emissions decreased as the cooling water temperature increased. When compared to diesel, the $\mathrm{NO}_{\mathrm{x}}$ values behaved differently for both loads $-\mathrm{NO}_{\mathrm{x}}$ emissions tend to increase at higher temperatures overall, except at $60 \%$ load. It was found that at $80 \%$ load, JO-BL blend gave lower $\mathrm{NO}_{x}$ levels than diesel even at $93{ }^{\circ} \mathrm{C}$ (Figure 4a). Biofuel smoke opacity emissions are directly related to $\mathrm{NO}_{\mathrm{x}}$ emissions (Figure 4b). However, in the case of diesel, smoke opacity and $\mathrm{NO}_{\mathrm{x}}$ emissions values were in opposite manner. Exhaust gas temperature is important for heating application in combined heat and power plant. For both fuels, the exhaust temperature increased, for all engine loads, as the temperature of the cooling water was increased (Figure 4c). The increased temperature of combustion produces exhaust gases at higher temperatures. Exhaust temperatures results for both diesel and biofuel blend were very similar to each other (Figure 4c).

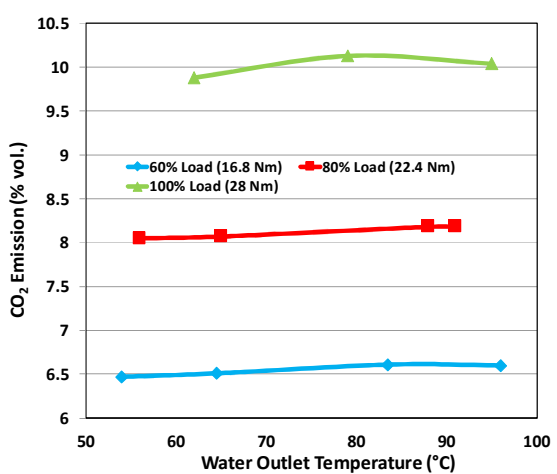

(a) fossil diesel: $\mathrm{CO}_{2}$ emissions

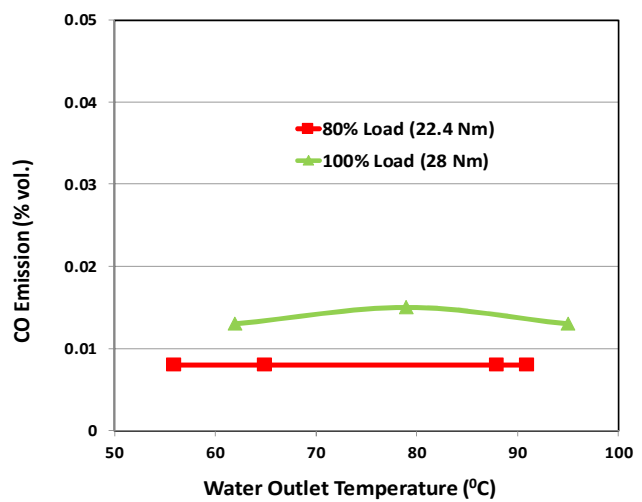

(b) fossil diesel: $\mathrm{CO}$ emissions

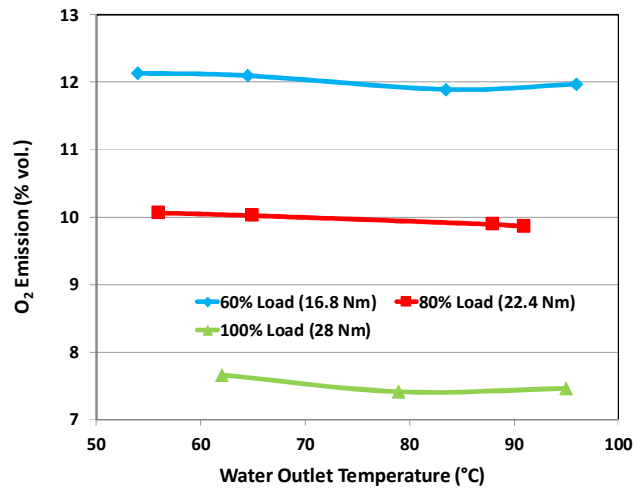

(c) fossil diesel: $\mathrm{O}_{2}$ emissions

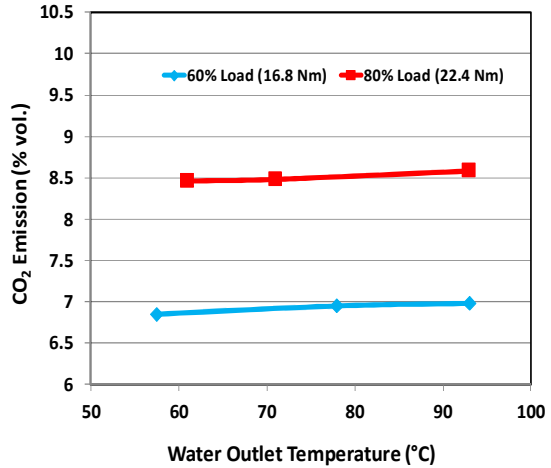

(a) biofuel: $\mathrm{CO}_{2}$ emissions

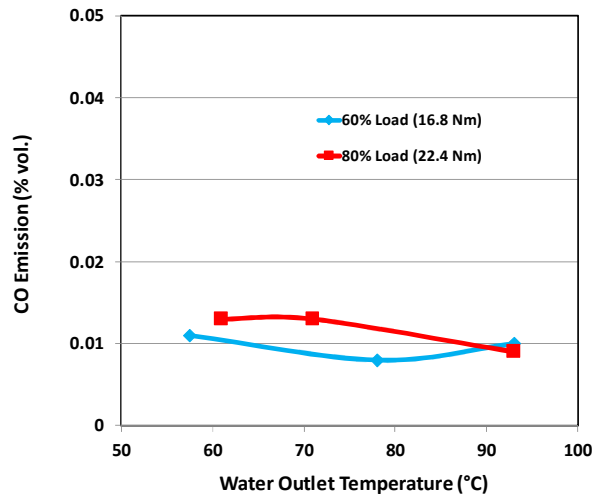

(b) biofuel: $\mathrm{CO}$ emissions

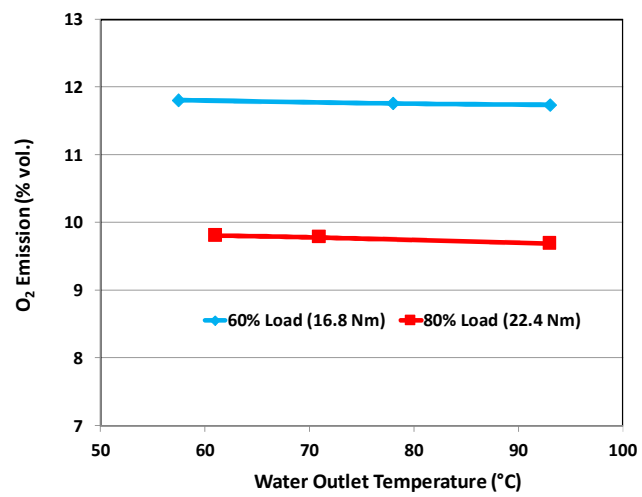

(c) biofuel: $\mathrm{O}_{2}$ emissions

Figure 3. Exhaust emissions results as a function of engine coolant temperature 


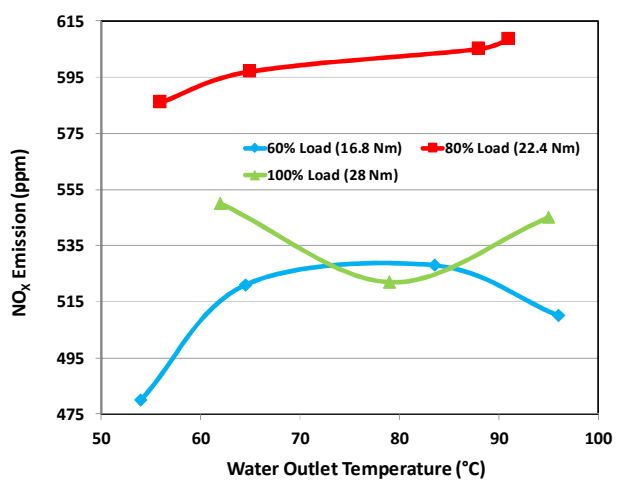

(a) fossil diesel: $\mathrm{NO}_{\mathrm{x}}$ emissions

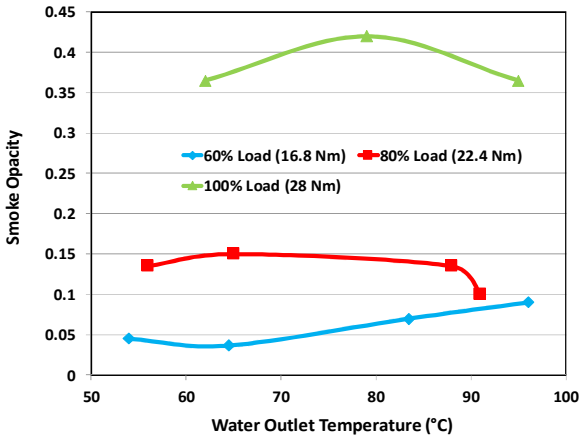

(b) fossil diesel: Smoke opacity

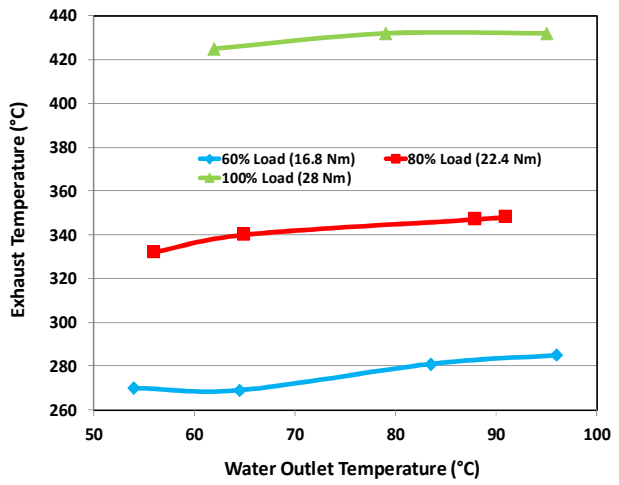

(c) fossil diesel: Exhaust temperature

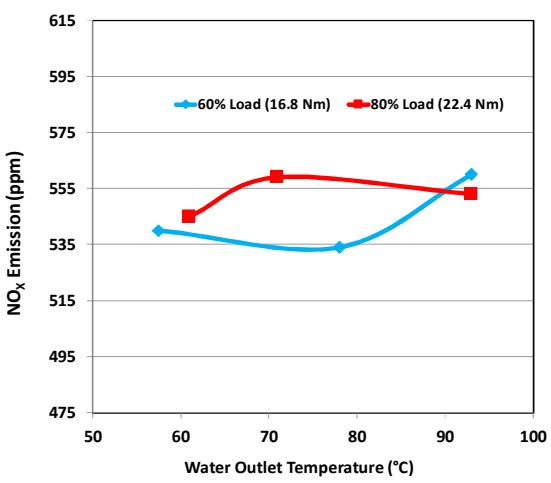

(a) biofuel: $\mathrm{NO}_{\mathrm{x}}$ emissions

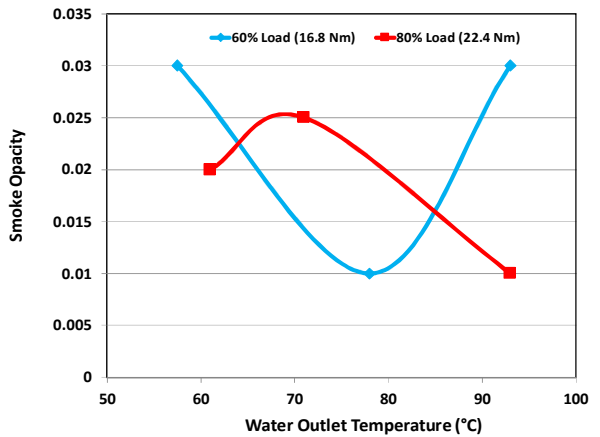

(b) biofuel: Smoke opacity

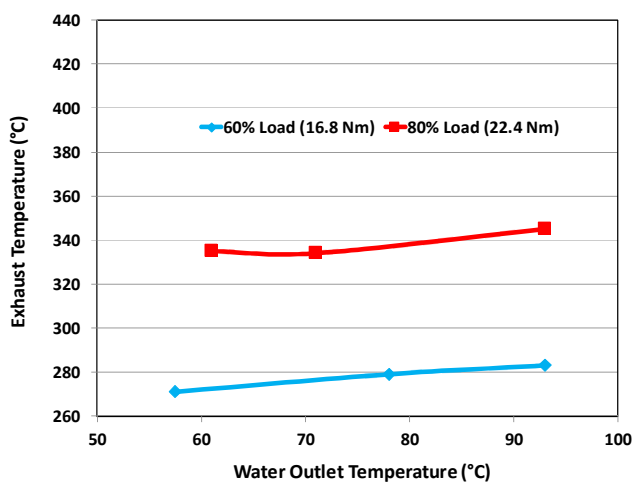

(c) biofuel: Exhaust temperature

Figure 4. $\mathrm{NO}_{\mathrm{x}}$, smoke emission and exhaust gas temperature results as a function of engine coolant temperature

Across all loads, Brake Specific Fuel Consumption (BSFC) of both fuels decreased, as the coolant temperature was increased (Figure 5a) - meaning less fuel is required to produce the same amount of power when the temperature of combustion is increased. Interestingly, at $60 \%$ load, biofuel BSFC value increased slightly with the cooling water temperature, before it gradually decreased (Figure 5a). When compared to diesel, biofuel BSFC values are higher at each load (Figure 5a). This is due to the difference in the properties of the two fuels. The biofuel was measured to have a lower heating value, therefore it was observed that the average BSFC was higher for the biofuel blend to provide the same power output, at all loads, when compared to diesel.

In addition, the higher viscosity of the biofuel blend also contributes to increasing the BSFC, as the viscosity affects the spray characteristics of the fuel during the injection period and high viscosity leads to less efficient mixing of the fuel with air. In general, for both fuels, the overall thermal efficiency increased as the temperature of the cooling water was increased (Figure 5b). The thermal efficiency is directly linked to the BSFC - 
the higher is the load higher is the efficiency due to the lower BSFC values at higher loads. The thermal efficiency of the biofuel blend is slightly higher when compared to diesel, for example, at $80 \%$ load; this is $3.5 \%$ higher than the corresponding diesel value. The oxygen content in biofuel is higher than fossil diesel. It was thought that micro-emulsion phenomenon (due to the BL component in the blend) and higher oxygen content in the biofuel blend helped to achieve higher brake thermal efficiency than fossil diesel. The volumetric efficiency is linked to the air flow rate. The air flow rate was observed to decrease with the increase in coolant temperature, but only very slightly; hence the volumetric efficiency decreased as the temperature of the cooling water was increased (Figure 5c), for all loads. This is similar to what was observed when diesel was used to operate the engine - for example, at $80 \%$ load; the biofuel volumetric efficiency is $1 \%$ higher as compared to diesel.

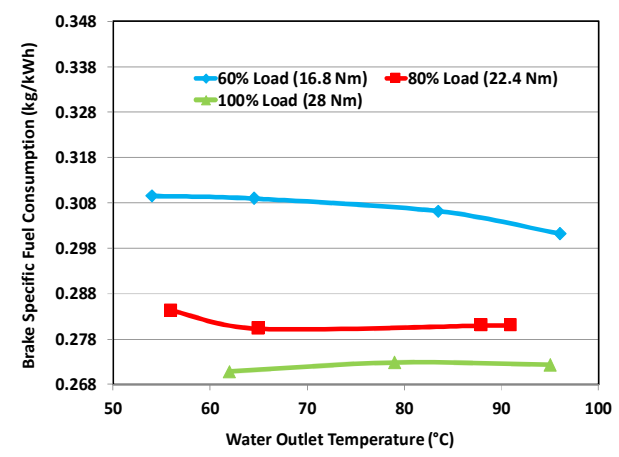

(a) fossil diesel: BSFC

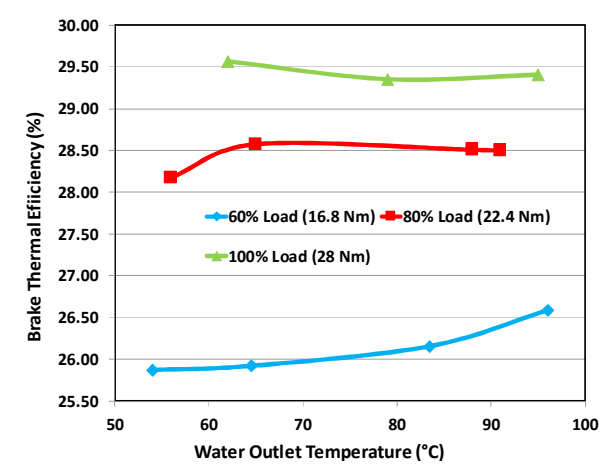

(b) fossil diesel: Thermal efficiency

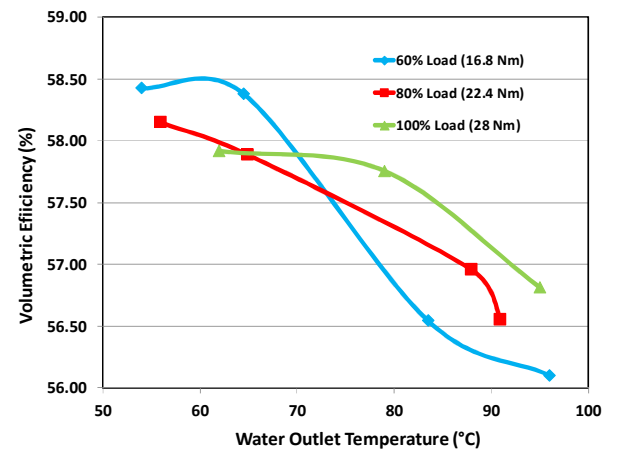

(c) fossil diesel: Volumetric efficiency

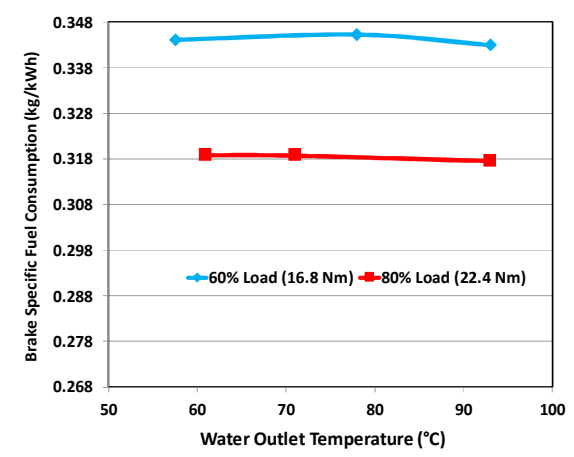

(a) biofuel: BSFC

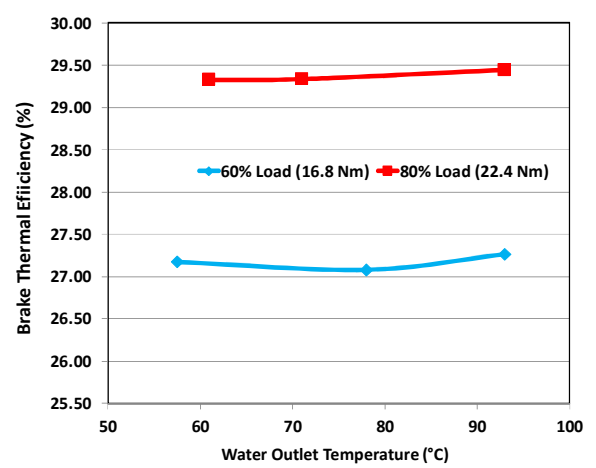

(b) biofuel: Thermal efficiency

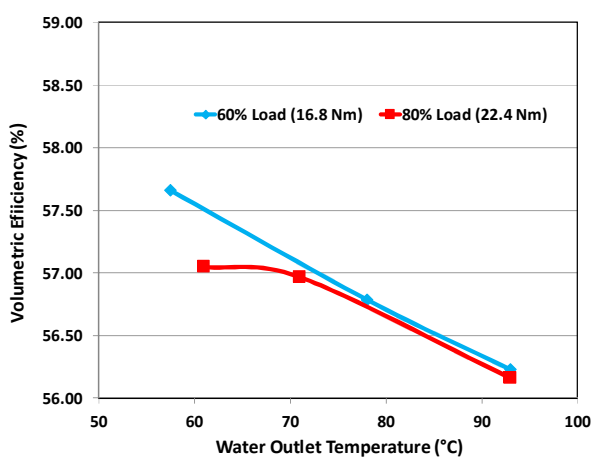

(c) biofuel: Volumetric efficiency

Figure 5. Results showing engine performance characteristics as a function of engine coolant temperature

\section{CONCLUSIONS}

Renewable alternatives such as biofuels and optimisation of the engine operating parameters can enhance engine performance and reduce emissions. In this study the fuel 
properties of fossil diesel, JO and JO-alcohol blends were measured; and biofuel blends properties were compared with the corresponding properties of fossil diesel. JO-BL blend was tested in a 2 cylinder, 4 -stroke, indirect injection CI engine to investigate the effect of cooling water temperature on engine performance and exhaust emission characteristics. The engine was operated at $60 \%, 80 \%$ and $100 \%$ loads and the cooling water temperature was varied between $50{ }^{\circ} \mathrm{C}$ and $95{ }^{\circ} \mathrm{C}$. It was found that blending $\mathrm{JO}$ with alcohols significantly improved the fuels properties of JO. Blend containing $80 \% \mathrm{JO}$ and $20 \% \mathrm{BL}$ was selected for engine testing due to better properties amongst all four biofuel blends.

Our initial study showed that effect of coolant temperature on engine performance and exhaust emission characteristics differ when the engine was operated on biofuel blend instead of diesel. The major findings of the study are summarised below:

- Overall, for both diesel and biofuel operation, the increase in the coolant temperature enhanced the combustion process. As a result of better combustion, $\mathrm{CO}_{2}$ emissions were increased. In general, it was found that both $\mathrm{CO}$ and $\mathrm{CO}_{2}$ emissions were higher, and $\mathrm{O}_{2}$ emissions values were lower, when the engine was operated with the biofuel blend, in comparison to diesel;

- At 80\% load, diesel $\mathrm{CO}$ and $\mathrm{O}_{2}$ emissions didn't change much with the increase in combustion temperature; whereas biofuel $\mathrm{CO}$ and $\mathrm{O}_{2}$ emissions decreased by about $31 \%$ and $6 \%$ respectively; when the temperature was increased from 60 to $90{ }^{\circ} \mathrm{C}$;

- Exhaust gas temperatures results for both diesel and biofuel blend were very similar to each other. No clear trends were observed on $\mathrm{NO}_{\mathrm{x}}$ and smoke emissions. At $80 \%$ load and at $90{ }^{\circ} \mathrm{C}$ temperature, JO-BL blend gave $10 \%$ lower $\mathrm{NO}_{\mathrm{x}}$ levels than diesel. The smoke and $\mathrm{NO}_{\mathrm{x}}$ gas emission trends were correlated in an identical manner for biofuel blend;

- For both fuels, the BSFC was observed to decrease with temperature. The thermal efficiency of the biofuel was found to be slightly higher than diesel. On the other hand, for both biofuel and diesel, the volumetric efficiency decreased slightly with the increase of coolant temperature.

Overall, it can be concluded coolant temperature does have significant influence on engine performance parameters and exhaust emission gases, and depends on the type of fuels and engines used. The coolant temperature for each biofuel blend needs to be established by carrying out engine tests for optimum engine performance and low exhaust gas emissions.

\section{ACKNOWLEDGEMENT}

The authors would like to thank Mr. Saleem Javed and Ms. Fatimah Khatoon (students of Aston University, UK) for their help during the experiments.

\section{REFERENCES}

1. BIOFUELNET, A Brief History of Biofuels: From Ancient History to Today, http://www.biofuelnet.ca/2013/07/31/a-brief-history-of-biofuels-from-ancient-histor y-to-today/, [Accessed: 03-April-2015]

2. Naik, S., Goud, V., Rout, P. and Dalai, A., Production of First and Second Generation Biofuels: A Comprehensive Review, Renewable and Sustainable Energy Reviews, Vol. 14, No. 2, pp 578-597, 2010, http://dx.doi.org/10.1016/j.rser.2009.10.003

3. Hossain, A. and Davies, P. A., Plant Oils as Fuels for Compression Ignition Engines: A Technical Review and Life-cycle Analysis, Renewable Energy, Vol. 35, No. 1, pp 1-13, 2010, http://dx.doi.org/10.1016/j.renene.2009.05.009

4. Hossain, A. K. and Davies, P. A., Pyrolysis Liquids and Gases as Alternative Fuels in Internal Combustion Engines - A Review, Renewable and Sustainable Energy 


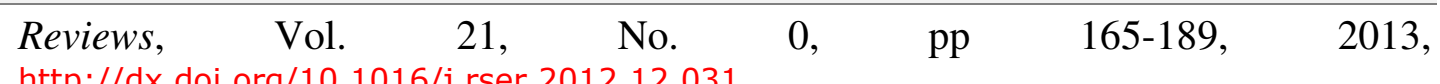

http://dx.doi.org/10.1016/j.rser.2012.12.031

5. Bergthorson, J. M. and Thomson, M. J., A Review of the Combustion and Emissions Properties of Advanced Transportation Biofuels and their Impact on Existing and Future Engines, Renewable and Sustainable Energy Reviews, Vol. 42, pp 1393-1417, 2015, http://dx.doi.org/10.1016/j.rser.2014.10.034

6. Sadeghinezhad, E. et al., A Comprehensive Literature Review of Bio-fuel Performance in Internal Combustion Engine and Relevant Costs Involvement, Renewable and Sustainable Energy Reviews, Vol. 30, pp 29-44, 2014, http://dx.doi.org/10.1016/j.rser.2013.09.022

7. Reham, S. S. et al., Study on Stability, Fuel Properties, Engine Combustion, Performance and Emission Characteristics of Biofuel Emulsion, Renewable and Sustainable Energy Reviews, Vol. 52, pp 1566-1579, 2015, http://dx.doi.org/10.1016/j.rser.2015.08.013

8. Rakopoulos, D. C., Rakopoulos, C. D. and Giakoumis, E. G., Impact of Properties of Vegetable Oil, Bio-diesel, Ethanol and n-butanol on the Combustion and Emissions of Turbocharged HDDI Diesel Engine Operating under Steady and Transient Conditions, Fuel, Vol. 156, pp 1-19, 2015 , http://dx.doi.org/10.1016/j.fuel.2015.04.021

9. He, B., Shuai, S., Wang, J. and He, H., The Effect of Ethanol Blended Diesel Fuels on Emissions from a Diesel Engine, Atmospheric Environment, Vol. 37, No. 35, pp 4965-4971, 2003, http://dx.doi.org/10.1016/j.atmosenv.2003.08.029

10. Rakopoulos, D., Rakopoulos, C., Kakaras, E. and Giakoumis, E., Effects of Ethanol-diesel Fuel Blends on the Performance and Exhaust Emissions of Heavy Duty DI Diesel Engine, Energy Conversion and Management, Vol. 49, No. 11, pp 3155-3162, 2008, http://dx.doi.org/10.1016/j.enconman.2008.05.023

11. Lujaji, F., Kristóf, L., Bereczky, A. and Mbarawa, M., Experimental Investigation of Fuel Properties, Engine Performance, Combustion and Emissions of Blends Containing Croton Oil, Butanol, and Diesel on a CI Engine, Fuel, Vol. 90, No. 2, pp 505-510, 2011, http://dx.doi.org/10.1016/j.fuel.2010.10.004

12. Şahin, Z. and Aksu, O., Experimental Investigation of the Effects of using Low Ratio n-butanol/diesel Fuel Blends on Engine Performance and Exhaust Emissions in a Turbocharged DI Diesel Engine, Renewable Energy, Vol. 77, pp 279-290, 2015, http://dx.doi.org/10.1016/j.renene.2014.11.093

13. Agarwal, D. and Agarwal, A., Performance and Emissions Characteristics of Jatropha Oil (Preheated and Blends) in a Direct Injection Compression Ignition Engine, Applied Thermal Engineering, Vol. 27, No. 13, pp 2314-2323, 2007, http://dx.doi.org/10.1016/j.applthermaleng.2007.01.009

14. Kumar, N., Bansal, S., Vibhanshu, V. and Singh, A., Utilization of Blends of Jatropha Oil and n-butanol in a Naturally aspirated Compression Ignition Engine, SAE Technical Paper 2013-01-2684, 2013.

15. Kumar, N. and Pali, H. S., Effects of n-butanol blending with Jatropha Methyl Esters on Compression Ignition Engine, Arabian Journal for Science and Engineering, pp 1-10, 2016, http://dx.doi.org/10.1007/s13369-016-2127-1

16. Agarwal, A., Gupta, T. and Kothari, A., Particulate Emissions from Biodiesel vs Diesel Fuelled Compression Ignition Engine, Renewable and Sustainable Energy Reviews, Vol. 15, No. 6, pp 3278-3300, 2011, http://dx.doi.org/10.1016/j.rser.2011.04.002

17. Imtenan, S., Varman, M., Masjuki, H., Kalam, M., Sajjad, H., Arbab, M. and Rizwanul Fattah, I., Impact of Low Temperature Combustion attaining Strategies on Diesel Engine Emissions for Diesel and Biodiesels: A Review, Energy Conversion and Management, Vol. 80, pp 329-356, 2014, http://dx.doi.org/10.1016/j.enconman.2014.01.020 
18. Burke, R., Brace, C., Hawley, J. and Pegg, I., Review of the Systems Analysis of Interactions between the Thermal, Lubricant, and Combustion Processes of Diesel Engines, Proceedings of the Institution of Mechanical Engineers, Part D: Journal of Automobile Engineering, Vol. 224, No. 5, pp 681-704, 2010, http://dx.doi.org/10.1243/09544070JAUTO1301

19. Chanfreau, B. G., Farkh, A. and Geels, P. Y., The need for an Electrical Water Valve in a Thermal Management Intelligent System (THEMISTM), SAE Paper 2003-01-0274, 2003.

20. Ogawa, K. R., Ilizuka, K. and Miyamoto., N., Cycle-to-cycle Transient Characteristics of Diesel Emissions during Starting, SAE Paper 1999-01-3495, 1999.

21. Ladommatos, S. M. A., Zhao, H. and Hu, Z., The Dilution, Chemical and Thermal Effects of Exhaust Gas Recirculation on Diesel Engine Emissions - Part 1: Effect of reducing Inlet Charge Oxygen, SAE Paper 961165, 1996.

22. Yoshizaki, K. N. and Hiroyasu, H., Approach to Low $\mathrm{NO}_{\mathrm{x}}$ and Smoke Emission Engines by using Phenomenological Simulation, SAE Paper 930612, 1993.

23. Torregrosa, A., Olmeda, P., Martín, J. and Degraeuwe, B., Experiments on the Influence of Inlet Charge and Coolant Temperature on Performance and Emissions of a DI Diesel Engine, Experimental Thermal and Fluid Science, Vol. 30, No. 7, pp 633-641, 2006, http://dx.doi.org/10.1016/j.expthermflusci.2006.01.002

24. Pang, H., Brace, C. and Akehurst, S., Potential of a Controllable Engine Cooling System to Reduce $\mathrm{NO}_{\mathrm{x}}$ Emissions in Diesel Engines, SAE Technical Paper 2004-01-0054, 2004.

25. Rehman, R. M. S., Dixit, S. and Pandey, R. K., Influence of Coolant Temperature on the Performance of a Four Stroke Spark Ignition Engine Employing a Dual Circuit Cooling System, Agric. Eng. Int.: CIGR Journal, Vol. 12, No. 1, pp 84-90, 2010.

26. Hossain, A. and Davies, P. A., Performance, Emission and Combustion Characteristics of an Indirect Injection (IDI) Multi-cylinder Compression Ignition (CI) Engine operating on Neat Jatropha and Karanj Oils Preheated by Jacket Water, Biomass and Bioenergy, Vol. 46, pp 332-342, 2012, http://dx.doi.org/10.1016/j.biombioe.2012.08.007

27. Kumar, S., Cho, J., Park, J. and Moon, I., Advances in Diesel-alcohol Blends and their Effects on the Performance and Emissions of Diesel Engines, Renewable and Sustainable Energy Reviews, Vol. 22, pp 46-72, 2013, http://dx.doi.org/10.1016/j.rser.2013.01.017

28. Campos-Fernández, J., Arnal, J., Gómez, J. and Dorado, M., A Comparison of Performance of higher Alcohols/diesel Fuel Blends in a Diesel Engine, Applied Energy, Vol. 95, pp 267-275, 2012, http://dx.doi.org/10.1016/j.apenergy.2012.02.051 